Anaquel de Estudios Árabes

ISSN-e: 1988-2645

http://dx.doi.org/10.5209/ANQE.55193

\title{
Ibn al-Jaṭīb y la poesía: El Kitāb A'mal al-a'lām, ejemplo de antología poética de al-Andalus
}

\author{
Víctor de Castro León ${ }^{1}$
}

Recibido: 28 de marzo de 2016 / Aceptado: 8 de febrero de 2017

Resumen. El presente estudio tiene por objeto la exposición y análisis de la poesía que el sabio granadino del s. XIV Ibn al-Jaṭịb incluyó en su obra histórica Kitāb A'māl al-a'lām. Estas muestras poéticas, algunas de gran extensión, constituyen una selecta antología de poesía andalusí de todas las épocas de la presencia islámica en la Península Ibérica.

Palabras clave: Kitāb A'māl al-a'lām; poesía; Ibn al-Jaṭīb; literatura andalusí; Nazaríes, Meriníes.

\section{[en] Ibn al-Jațīb and the poetry: The Kitāb A'māl al-a'lam, example of poetic anthology of al-Andalus}

\begin{abstract}
The present study offers the presentation and analysis of poetry of the fourteenth century Grenadian wise Ibn al-Khațīb included in his historical work Kitāb A'māl al-a'lām. These poetic samples, some of which are very extensive, constitute a select anthology of andalusian poetry from all eras of Islamic presence in the Iberian Peninsula.
\end{abstract}

Keywords: Kitāb A'māl al-a'lām; poetry; Ibn al-Khațīb; andalusian literature; Nasrids, Merinids.

Sumario: 1. Presentación. 2. La poesía del Kitāb A'māl al-a'lām.

Cómo citar: De Castro León, V. (2017) Ibn al-Jațīb y la poesía: El Kitāb A'mal al-a'lām, ejemplo de antología poética de al-Andalus, en Anaquel de Estudios Árabes 28, 51-77.

Universidad de Salamanca 


\section{Presentación}

El sabio lojeño del s. VIII/XIV Ibn al-Jațī ${ }^{2}$ ha pasado a la posterioridad como hombre de letras, médico, filólogo, místico, astrólogo, geógrafo, poeta, gramático, historiador, etc., pero por encima de todo ello, como una de las figuras más destacadas del humanismo andalusí. Puede afirmarse que fue, posiblemente junto con el sabio tunecino Ibn Jaldūn, la figura intelectual y política más importante del s. VIII/XIV. Nacido en Loja, Granada (713/1313-776/1374) y educado en todas las materias y saberes de su época, se convirtió en el célebre secretario y jefe de la cancillería nazarí y en el poderoso visir del reino de Granada durante el periodo de mayor esplendor de este, los reinados del sultán Yūsuf I (733/1333-755/1354) y Muḥammad V (755/1354- 760/1359 y 763/1362- 793/1391). Personalidad de gran talla que mantuvo relaciones diplomáticas, de amistad e incluso de odio con las más influyentes figuras de su siglo, tanto de la política como de la cultura, como lo fueron Ibn Marzūq, Ibn al-Ŷayyāb, Ibn Jaldūn, el cadí al-Bunāhī, Ibn Zamrak, el rey Pedro I de Castilla y los sultanes meriníes Abū Sālim y Abū Fāris 'Abd al-'Azīz. En el año 773/1371 cansado de la labor cortesana y desgastado por toda una vida llena de intrigas, poder, ambiciones, conspiraciones y desgracias, decidió huir del reino granadino rumbo al reino meriní del sultán 'Abd al-'Azīz, bajo cuya protección, y posteriormente bajo la de su hijo menor de edad Abū Zayyān Muhammad al-Sa'îd II y la de su poderoso regente y visir Abū Bakr b. Gāzī, pasó los últimos años de su vida, mientras desde Granada era acusado de traición, deslealtad y herejía. En el año 776/1374 una serie de acontecimientos adversos hicieron que Ibn al-Jațīb fuese encarcelado y asesinado en prisión por sus enemigos granadinos y magrebíes.

Ibn al-Jațīb es famoso tanto por su obra como por su vida, lo que ha despertado siempre gran interés, hasta el punto de llamar la atención de los estudiosos e investigadores en todas las épocas y en todos los lugares. Existen, en definitiva, razones más que sobradas que justifican este gran interés por su figura y producción intelectual.

Para una información detallada sobre la vida de este autor, véase la extensa entrada de Lirola Delgado, J., "Ibn al-Jațīb al-Salmān̄̄, Lisān al-Dīn” en Biblioteca de Al-Andalus, Fundación Ibn Tufayl de Estudios Árabes, Almería, 2004, 643-698, las monografías de Bosch Vilá, J., Ben al-Jațīb y Granada, Asociación Cultural Hispano Alemana, Madrid, 1980 y Molina López, Emilio, Ibn al-Jatib, Granada, 2001. Los estudios y trabajos sobre su persona y obra son tan extensos que sería imposible citarlos todos aquí. Los más recientes han sido efectuados con motivo de varios encuentros dedicados a su persona, recogidos en varias publicaciones, a destacar: "Numéro spécial sur le colloque d 'Ibn Al Khatib" en Revue de la Faculté de Lettres de Tetouan n², 1987, Actas del 1er Coloquio Internacional Sobre Ibn al-Jatib, Granada, 2007, Ibn al-Jațīb y su tiempo, Granada, 2012 y Saber y poder en al-Andalus. Ibn al-Jațīb (s. XIV), Córdoba, 2014. También es de destacar los recientes trabajos de Ženka, Josef, "Las terceras taifas en un nuevo manuscrito del A'māl/I'māl al-a' lām de Ibn al-Jațīb" en Manuscritos árabes en Marruecos y en España: espacios compartidos. Sexta Primavera del Manuscrito Andalusí, eds. Mostafa Ammadi, Francisco Vidal Castro y Ma Jesús Viguera Molins, Casablanca, 2013, 181-190; “The Great Ruling Family of the fourteenth Century: Mușāhara in the Age of Ibn al-Khațīb” en Medieval Encounters, 20, Brill-Leiden, 2014, 309-339; Fernando N. Velázquez Basanta, "Carta jocosa de Ibn al-Jațīb al mojaqueño y preceptor de gramática Ibn al-Fajjār al-Bayrī” en Revista de Estudios sobre Patrimonio, Cultura y Ciencias Medievales, $n^{\circ} 17,2015,419-424$ y su reciente traducción de la obra Jaṭra al-țayf wa-riḥlat al-šitā’ wa-l-ṣayf de Ibn al-Jațīb bajo el título Visión de la amada ideal en una gira inverniza y estival, Córdoba: Fundación Ibn Tufayl de Estudios Árabes, 2016 y Humayun Akhtar, Ali, “The political controversy over graeco-arabic philosophy and sufism in nasrid goverment: The case of Ibn al-Khatib in al-Andalus" en International Journal of Middle East Studies, v. 47, n 2 , 323-342. 
Autor de aproximadamente setenta obras, muchas de las cuales no han llegado hasta nosotros hoy en día, los estudios e investigaciones actuales en los últimos años se han centrado en desentrañar sus motivaciones personales, en especial su controvertida faceta mística y sus inquietudes políticas y vitales presentes en muchas de sus obras, en especial la que es objeto de este estudio, el Kitāb A'māl al-a'lām fì man būyi a qabla al-iḥtilām min mulūk al-islām wa mā yaŷurru dâ̄lika min šuŷūn al-kalām (Libro de las gestas de los hombres ilustres acerca de los reyes del islam que fueron proclamados antes de alcanzar la pubertad, con lo que ello conlleva de digresiones), obra que compuso en Fez entre los años 774-776/1372-1374, mientras residía exiliado en la corte meriní bajo la protección del visir Ibn Gāzī, tutor del joven sultán menor de edad al-Sa'īd II.

Como es sabido, el Kitāb A'māl al-a'lām es una historia general del islam inacabada, dividida en tres partes. La primera de ellas está dedicada a la historia de las dinastías musulmanas de Oriente, la segunda, que es el objeto de estudio de este artículo, se ocupa de la conquista y la presencia islámica en la Península Ibérica, y la tercera se centra en la historia del Magreb y de Sicilia, parte que por razones que todavía no están del todo claras, quedó inacabada, ya que la obra según su autor debía finalizar con el elogio de la dinastía meriní ${ }^{3}$ y en cambio termina con el capítulo incompleto de la dinastía almohade ${ }^{4}$.

Es evidente que esta crónica - que fue posiblemente la última obra escrita en vida por Ibn al-Jațīb, lo que le da un valor añadido por las circunstancias especiales en las que la compuso - ha pasado a la posteridad por su valor histórico y por los testimonios personales que el autor insertó al final de la segunda parte de la obra, a modo de capítulo autobiográfico ${ }^{5}$, en los que nos narra su experiencia vital y política durante el segundo reinado del sultán Muhammad V hasta su exilio y persecución en Tremecén y Fez. Sin duda, su valía histórica y personal es incuestionable, y así ha sido puesto de relieve en los últimos años por numerosos estudios e investigaciones. Pero si abrimos nuestra mirada fuera del marco documental y geográfico, podremos ver que esta obra encierra en su interior un valioso documento, no sólo artístico, sino también histórico, como es el de las numerosas muestras poéticas que aquí y allá salpican el texto de la crónica y a su vez adornan, completan y embellecen el relato prosístico de la narración de los sucesivos acontecimientos históricos, constituyendo, en definitiva, una selecta y auténtica antología poética.

\footnotetext{
La edición que he manejado para la traducción de la segunda parte de la obra ha sido la efectuada por LéviProvençal, E., Histoire de l'Espagne Musulmane, Beirut, 1956. Es sin duda la mejor edición existente hasta la fecha, ya que contamos con otra edición más reciente, pero de peor calidad, la realizada por Sayyid Kasrawī Ḥasan, Abū Islām, Kitāb A'māl al-a'lām, Beirut, 2003, donde realiza la edición de las tres partes de la obra, tomada de una copia egipcia deteriorada de uno de los dos manuscritos existentes de la obra en la Biblioteca General de Rabat.

4 Véase Ibn Al-Jațīb, Kitāb A'māl al-a'lām, ed. Lévi Provençal, Beirut, 1956, 3-4 y ed. de Sayyid Kasrawī Ḥasan, Beirut, 2003, 44 y ss.

5 Véase Ibn Al-Jațīb, Kitāb A'māl al-a'lām, ed. Lévi-Provençal, Beirut, 1956, 310-323.
} 


\section{La Poesía Del Kitāb A'māl al-a'lām ${ }^{6}$}

Basta con una primera ojeada a la segunda parte del Kitāb A'māl al-a'lām para darnos cuenta de que la presencia de la poesía en sus páginas es cuantiosa y nada ocasional, son numerosas las muestras poéticas. De hecho dentro de esta obra, y en concreto en su segunda parte, se encierra una selecta y amplia antología poética, sobre todo de autores andalusíes, lo que demuestra el aprecio y estima que Ibn al-Jațīb tenía por la poesía andalusí y sus autores.

$6 \quad$ Sobre la poesía y en particular sobre la faceta poética de Ibn al-Jațīb véase Garulo, Teresa, “En torno a Granada. Reflexiones sobre la poesía en la época almorávide" en Qurțuba, n 4, 1999, 73-96, Chafic Damaj, Aḥmad, "Relación entre el poeta y el poder político en la época de Taifas: de la concordia a la discrepancia" en Meah, v. 53, 2004, 3-38 y "El panegírico al servicio del gobernante en la Granada nazarí. Las bases de su contenido" en Meah, v. 54, 2005, 29-38, Del Moral, Celia, "Notas para el estudio de la poesía árabe-granadina" en Meah, v. 32-33, 1983-1984, 55-94, "Aportación al estudio de la métrica árabe a través del Dīwān de Ibn al-Jațīb y de otros poetas del reino nazarí" en Meah, v. 37, 1988, 183-194 y "Sobre la utilidad de la poesía en al-Andalus: Las ijwāniyyāt, un género ignorado" en Meah, v. 56, 2007, 175-203, Chakor Alami, Khalid, "Contribution a l'étude de la métrique árabe dans la poésie Nașride du XIV e siècle” en Meah, v. 47, 1998, 89-111, Continente Ferrer, J. M., "El «Kitāb al-siḥr wa-l-ši'r» de Ibn al-Jațīb (Libro de la magia y de la poesía)" en Al-Andalus, 1973, 393414 y "La qasida de Lisān al-Dīn Ibn al-Jaṭīb titulada: al-Manḥ al-garīb fi-l-fatḥ al-qarīb” en Actas de las II Jornadas de Cultura Árabe e Islámica, Madrid, 1985, 73-117, Gibert, Soledad, "Algunas curiosidades de la poesía arábigoandaluza" en A1-Andalus, 1968, 95-122, Eazah Alzahrani, Saleh, Aspectos culturales e ideológicos en el Dīwān de Lisān al-Dīn Ibn al-Jațīb, Tesis Doctoral dirigida por Celia del Moral, Universidad de Granada, 2011, "La queja y la elegía, dos elementos fundamentales de la melancolía en el Dīwān de Ibn al-Jațīb" en Meah, nº 57, 2008, 301-325 y "Lo cómico y lo burlesco en el Dīwān de Ibn al-Jațīb" en Ibn al-Jațīb y su tiempo, Granada, 2012, 289-306, Rubiera Mata, Ma J., La arquitectura en la literatura árabe, Madrid, 1981, García Gómez, E., Poemas árabes en los muros y fuentes de la Alhambra, Instituto Egipcio de Estudios Islámicos, Madrid, 1996 y Velázquez Basanta, F.N., "Nota bio-bibliográfica sobre Ibn al-Jațīb" en Ibn al-Jațīb y su tiempo, Granada, 2012, 263-285. En lengua árabe aparecieron varios estudios sobre su poesía en el número monográfico dedicado a su persona en la Revista de la Facultad de Letras de Tetuán (Maŷallat kullīyat al-Ādāb bi-Tițwān), $n^{\circ}$ 2, 1987: Bencherifa, Muhammad, "Min al-ŷadīd fị ši'r Ibn al-Jațīb”, 237-247, Al-Ṭurrīsī, Aḥmad, "Ša'irīyat Ibn al-Jațīb”, 249-256, Al-Šāmī, 'Abd al-Malik, "Dirāsa fī mawlidīyāt Ibn al-Jațīb”, 257-274, Al-Ḥusaynī, Qāsim,

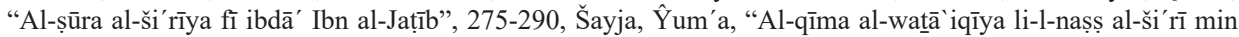
jilāl ši'r al-wazīr Ibn al-Jațīb”, 291-324 y Țaḥțạ̣, Fāțima, “Al-taŷriba al-dīnīya fĩ ši'r Ibn al-Jațīb”, 325-333. Otros destacados estudios en árabe son: Ibn AL-BAŠĪR, Muḥammad, "Ši'r Ibn al-Jațīb wa muwaššaḥatu-hu" en Al-Bayyina, n 7, 1962, 49-65, AL-AMĪN, Wahhāb, Ši'r Lisān al-Dīn Ibn al-Jațīb wa jașā ișu-hu al-fannīya, tesina presentada en la Universidad del Cairo, 1980 y Al-SIrgīn̄i, Bennāșir, "Ibn al-Jațīb al-Zaŷŷāl” en Da'wat al-Haqq, $\mathrm{n}^{\circ}$ 10, 1975, 115-121. 
Ibn al-Jațīb fue ante todo, además de intelectual y prosista, un excelente poeta, especialmente cortesano, que compuso piezas de todos los géneros posibles y de todos los metros existentes. Compiló su poesía en su propio dīwān titulado al-Șayyib wa1-ŷahām wa-l-māḍī wa-l-kahām ${ }^{7}$ (La [nube] lluviosa y la seca, y el [sable] afilado y el mellado), compuso varias antologías poéticas, entre las que destacan el Kitāb al-Siḥr wa al-ší ${ }^{8}{ }^{8}$ Libro de la magia y de la poesía) y al-Katība al-kāmina fì man laqīnā-hu bi-l-Andalus min šu' arā' al-mi'a al-țāmina9 (El escuadrón al acecho, acerca de los poetas del siglo VIII que encontré en al-Andalus), compiló los dīwān-s de otros compañeros y maestros suyos, como el Dīwān de Aḥmad b. Ṣafwān, titulado al-Durar al-fājira wa-l-luŷaŷ al-zājira (Perlas preciosas y mares desbordantes) y el Dīwān de Ibn al-Ŷayyāb. A su vez, escribió numerosas urŷūzas, poemas didácticos en metro raŷaz, de muy diversa temática: política, alimentación, medicina, derecho, historia, etc. Entre ellas destaca al-Siyāsa al-madanīya (Política civil), Raŷaz al-țibb (Poema en metro raŷaz sobre medicina), Raqm al-ḥulal fĩ nazm al-duwal (El recamado de las vestiduras, sobre la sarta de las dinastías) y al-Manh al-garīb fì l-fath al-qarīb (Regalo extraordinario sobre la cercana conquista), además de muchas otras composiciones.

El sabio lojeño cultivó la poesía durante toda su vida, caracterizándose aquélla por la cantidad, la calidad y la perfección formal, dados sus elevados conocimientos y dominio de la lengua árabe. La mayor parte de su poesía es de carácter oficial, poesías que en muchos casos son del género sulțanīyāt (en alabanza al califa, al sultán o al emir), pero también cultivó el resto de géneros: poesía descriptiva, amorosa, religiosa, mística, báquica, satírica, crítica, sapiencial, ijwānīyāt (elogio a un amigo o a algún personaje de la corte), el zéjel y la moaxaja, siendo autor de una antología de moaxajas titulada Ŷayš al-tawš̄ị (Tropa de composiciones de moaxajas) ${ }^{10}$.

La poesía fue, durante la época en la que el sabio granadino vivió, el arte más cultivado por los andalusíes. Se pensaba, y para ellos era cierto, que para que un poeta fuese consagrado y alcanzase el reconocimiento por el resto de los tiempos debía haber cultivado todos los temas y géneros, e Ibn al-Jațīb era consciente de esto. Por ello buscó el reconocimiento de sus contemporáneos y de la posteridad, y fue considerado con justicia el poeta que mejor describió su época y reflejó las tendencias artísticas de su tiempo.

7 Edición en dos tomos por Miftāḥ, Muhammad, Dīwān Lisān al-Dīn Ibn al-Jațīb al-Salmānī, Beirut, 1989.

8 Edición y traducción al castellano por Continente Ferrer, J. M., Madrid, 1981. Hay una edición posterior, sin índices, de Kamāl Šabbāna, Muḥammad y Ḥasan Aa-Ŷamal, Ibrāhīm Muḥammad, El Cairo, 1999.

9 Edición de 'Abbās, Iḥsān, Beirut, 1963, a partir del manuscrito nº 12395 Z, conservado en la biblioteca de Dār al-Kutub al-Mișrīya en El Cairo.

10 Hay varias ediciones de esta obra pero la más completa, empleando todos los manuscritos existentes, es la efectuada por Jones, Alan, The Jaysh al-tawshīh of Lisān al-Dīn Ibn al-Khațīb. An anthology of Andalusian Arabic Muwashshahāt, Cambridge, 1997. 
Esta breve disquisición es para dar a entender que Ibn al-Jațīb fue poeta, hombre de letras, antólogo, crítico y teórico de la lengua, por lo que la poesía inserta en sus obras no es casual ni está recogida sin criterio aparente, al contrario, todas las piezas de poesía responden a un propósito meditado y concreto, y que por lo general, es de dos clases: Por una parte, hay un criterio estético o estilístico, la belleza de la poesía en sí misma. Y por otro lado, hay un valor histórico, su poesía es también una fuente de datos, y en ocasiones mejor que las propias obras históricas, ya que éstas se escriben a veces muchos años después de los hechos narrados. En cambio, los poemas suelen ser contemporáneos de los acontecimientos, se componen en el acto o muy poco después, lo que nos proporciona una valiosísima información en la que el suceso histórico está descrito con más precisión debido a la mayor frescura de la memoria del autor. Además, en los poemas el poeta nos proporciona detalles que no se suelen dar en las obras en prosa.

En el Kitāb A'māl al-a'lām aparecen un total de 75 poemas o piezas poéticas que suman un total de 889 versos, lo que supone una muestra poética considerable ${ }^{11}$ . En primer lugar, y de manera resumida, expondremos detalladamente por orden de aparición todas las piezas poéticas existentes en la obra, haciendo referencia a su autor, tema, número de versos, rima, metro y páginas en las que se encuentra en la edición de E. Lévi-Provençal, Beirut, 1956. No haremos referencia a la otra edición manejada del Kitāb A'māl al-a'lām, la de Sayyid Kasrawī, porque en ella la mayoría de las piezas poéticas no son recogidas o aparecen incompletas debido al deterioro de los manuscritos en los que se basa la edición, a diferencia del texto en prosa que aparece con mayor calidad. Después de esta exposición analizaremos brevemente la poesía recopilada, atendiendo a los diferentes y más importantes estudios que sobre métrica árabe han sido realizados en los últimos tiempos.

Las poesías incluidas por Ibn al-Jațīb en la segunda parte del Kitāb A'māl al-a'lām son:

1. Abū Ishạāq b. Jafāŷa. Tema: Poema descriptivo (waṣf) en elogio de al-Andalus. Metro: Basīṭ. Rima: ru. $\mathbf{N}^{\mathbf{o}}$ de versos: 2. Página/s: 5 del texto árabe.

2. 'Abd al-Raḥmān I, emir omeya de al-Andalus. Tema: Poema amorosonostálgico (gazal) por la separación de su tierra de origen en Oriente. Metro: jafîf. Rima: di. $\mathbf{N}^{\mathbf{0}}$ de versos: 4 . Página/s: 10.

3. 'Abd al-Raḥmān I, emir omeya de al-Andalus. Tema: Poema amorosonostálgico por la separación de su tierra de origen en Oriente. Metro: țawīl. Rima: li. $\mathbf{N}^{\mathbf{0}}$ de versos: 3. Página/s: 10.

4. Ibn al-Jațīb. Tema: Poema de queja (šakwà)-moral (ḥikma) contra sus opositores, contrarios a los cargos que desempeñaba el autor en la corte nazarí. Metro: jafif. Rima: ri. $\mathbf{N}^{\mathbf{0}}$ de versos: 14 . Página/s: 13.

11 Todas las traducciones que aparecen en este artículo, tanto de prosa como de poesía, han sido realizadas íntegramente por mi persona y forman parte del texto de la Tesis Doctoral, Ibn al-Jațîb: símbolo de la cultura andalusí del Reino nazarí de Granada. Análisis y traducción al castellano del Kitāb A'māl al-a'lām, Universidad de Salamanca, 2015. 
5. Al-Ḥakam I, emir omeya de al-Andalus ${ }^{12}$. Tema: Poema amoroso sobre unas esclavas de las que estaba enamorado el emir. Metro: jafíf. Rima: kā. No de versos: 5. Página/s: 17-18.

6. 'Abd Allāh b. al-Šamir, poeta de 'Abd al-Raḥmān II. Tema: Poema amoroso-nostálgico por la separación del ser amado. Metro: mutaqārib. Rima: bā. $\mathbf{N}^{0}$ de versos: 6 . Página/s: $18-19$.

7. 'Abd al-Raḥmān II, emir omeya de al-Andalus. Tema: Poema moral-sapiencial (hikma) sobre la importancia de la experiencia en el ser humano. Metro: kāmil. Rima: hā. No de versos: 2. Página/s: 19.

8. Hāšim b. 'Abd al-'Azīz. Tema: Elegía (ritāa') al emir omeya Muhammad I. Metro: wāfir. Rima: mi. $\mathbf{N}^{\mathbf{0}}$ de versos: 2. Página/s: 24.

9. Hāšim b. 'Abd al-'Az̄̄z. Tema: Amoroso-nostálgico (gazal) por la separación de una esclava llamada 'Âŷ, al encontrarse el poeta en la cárcel. Metro: țawīl. Rima: bu. $\mathbf{N}^{\mathbf{0}}$ de versos: 7. Página/s: 25.

10. 'Abd Allāh, emir omeya de al-Andalus. Tema: Amoroso-nostálgico (gazal), acerca del sufrimiento que padece el enamorado. Metro: sarī'. Rima: k. $\mathbf{N}^{\mathbf{0}}$ de versos: 4. Página/s: 26-27.

11. 'Abd Allāh, emir omeya de al-Andalus. Tema: ascético-místico (zuhr) sobre la muerte. Metro: kāmil. Rima: 1 . No de versos: 3. Página/s: 27.

12. Anónimo. Tema: Sapiencial-gnómico (hikma) sobre las virtudes del gobernante. Metro: jafif. Rima: ri. $\mathbf{N}^{\mathbf{0}}$ de versos: 2. Página/s: 29.

13. Ibn 'Abd Rabbihi, poeta de 'Abd al-Raḥmān III. Tema: Panegírico-elogio (sulțānīya) a 'Abd al-Raḥmān III. Metro: basîṭ. Rima: ŷă. $\mathbf{N}^{0}$ de versos: 2 . Página/s: 30 .

14. Ibn 'Abd Rabbihi, poeta de 'Abd al-Raḥmān III. Tema: Panegírico-elogio (sultān̄īya) a Ibrāhīm b. al-Ḥaŷŷâŷ, rebelde y señor de Sevilla en la época de Abd al-Raḥmān III. Metro: wāfir. Rima: du. No de versos: 1. Página/s: 35.

15. Ŷa'far b. 'Uțmān al-Muṣ̣̣āfī, secretario de 'Abd al-Raḥmān III. Tema: Elegía (ritāa') a 'Abd al-Raḥmān III. Metro: țawīl. Rima: hā. $\mathbf{N}^{0}$ de versos: 6 . Página/s: 40 .

16. Ibn Hāni', poeta de al-Ḥakam II. Tema: Panegírico-elogio (sulțānīya) al emir del Zāb, Yahyà b. 'Alī. Metro: țawīl. Rima: fā. $N^{0}$ de versos: 1. Página/s: 42.

Véase sobre este emir omeya y su poesía, Velázquez Basanta, F. N., "Al-Ḥakam I visto por Ibn al-Jaṭịb", Qurțuba: estudios andalusíes, v. 3, 1998, 171-179. 
17. Ŷa'far b. 'Uțmān al-Muṣḥāfī, secretario de 'Abd al-Raḥmān III. Tema: Felicitación (sultānnìya) al califa por el nacimiento de su hijo Hišām II. Metro: wāfir. Rima: mi. $\mathbf{N}^{\mathbf{0}}$ de versos: 4. Página/s: 42-43.

18. Ŷa'far b. 'Uțmān al-Muṣhāfī, secretario de 'Abd al-Raḥmān III. Tema: Felicitación (sultānīya) al califa por el nacimiento de su hijo Hišām II. Metro: mujalla' al-basìt. Rima: hi. $\mathbf{N}^{0}$ de versos: 4. Página/s: 43.

19. Qays b. al-Mulawwaḥ, el loco enamorado de Laylà. Tema: Amor-nostálgia (gazal) por la separación de la amada. Metro: țawīl. Rima: yā. $\mathbf{N}^{\mathbf{0}}$ de versos: 1. Página/s: 45.

20. Anónimo. Tema: Sapiencial-moral (ḥikma) sobre la mujer. Metro: maŷzū’ al-jafif. Rima: di. No de versos: 1 . Página/s: 45.

21. Șā'id b. al-Ḥasan al-Bagdādī. Tema: Panegírico-elogio (sulțānīya) a Almanzor tomando como pretexto un cervatillo de regalo. Metro: kāmil. Rima: li. $\mathbf{N}^{\mathbf{0}}$ de versos: 5. Página/s: 69.

22. Șā'id b. al-Ḥasan al-Bagdādī. Tema: Panegírico-elogio (sultān̄īya) a Almanzor felicitándole por su victoria en la campaña del año 390/1000. Metro: kāmil. Rima: di. No de versos: 15 . Página/s: 72-73.

23. Ibn Zamrak, discípulo de Ibn al-Jațīb. Tema: Sátira (hiŷā') contra el cadí de Granada Abū al-Ḥasan al-Nubbāhī. Metro: țawīl. Rima: ri. No de versos: 4. Página/s: 79-80.

24. Anónimo. Tema: Panegírico-elogio (sultānīya) a 'Abd al-Malīk b. Abī 'Āmir al-Muzaffar, hijo y sucesor de Almanzor. Metro: no se especifica. Rima: ri. $\mathbf{N}^{0}$ de versos: 1 . Página/s: 87.

25. Șā'id b. al-Ḥasan al-Bagdādī. Tema: Panegírico-elogio (sulțānīya) a 'Abd al-Raḥmān b. Abī 'Āmir Sanchuelo, hijo de Almanzor, felicitándole por su nombramiento como futuro heredero. Metro: țawīl. Rima: lā. $\mathbf{N}^{\mathbf{0}}$ de versos: 4. Página/s: 94.

26. Abū Manșūr Ziyādat Allāh al-Ḍabbī. Tema: Panegírico-elogio (sulțānīya) a 'Abd al-Raḥmān b. Abī 'Āmir Sanchuelo, felicitándole por su nombramiento como futuro heredero. Metro: basīt. Rima: mi. $\mathbf{N}^{\mathbf{0}}$ de versos: 3 . Página/s: 94.

27. Abū Manșūr Ziyāda 'Allāh al-Ḍabbī. Tema: Panegírico-elogio (sulțānīya) a 'Abd al-Raḥmān b. Abī 'Āmir Sanchuelo, felicitándole por su nombramiento como futuro heredero. Metro: kāmil. Rima: qā. $\mathbf{N}^{0}$ de versos: 6. Página/s: 94-95. 
28. Qāsim b. Mạ̣mūd al-Marwān̄ī, poeta de los 'āmiríes. Tema: Panegíricoelogio (sultānīya) a 'Abd al-Raḥmān b. Ab̄̄ 'Āmir Sanchuelo, felicitándole por su nombramiento como futuro heredero. Metro: țawīl. Rima: dā. $\mathbf{N}^{\mathbf{0}}$ de versos: 10 . Página/s: 95.

29. Secretario de la redacción de epístolas, cliente de los Banū Marwān. Tema: Panegírico-elogio (sulțānīya) a 'Abd al-Raḥmān b. Ab̄̄ 'Āmir Sanchuelo, felicitándole por su nombramiento como futuro heredero y también elogio a Hišām II. Metro: kāmil. Rima: qā. $\mathbf{N}^{0}$ de versos: 11. Página/s: 9596.

30. Ibn Šuhayd. Tema: Elegía (ritā’) a la ciudad de Córdoba por su destrucción ocasionada con la caída de los 'āmiríes y la sublevación de Muhammad II b. 'Abd al-Ŷabbār al-Mahdī. Metro: kāmil. Rima: ru. $\mathbf{N}^{\circ}$ de versos: 30 . Página/s: 105-106.

31. Ibn Hazm de Córdoba. Tema: Elegía (ritāa) a Córdoba por su destrucción ocasionada con la caída de los 'āmiríes y la sublevación Muhammad II b. 'Abd al-Ŷabbār al-Mahdī. Metro: țawīl. Rima: rā. $\mathbf{N}^{0}$ de versos: 20. Página/s: 107-108.

32. Califa abasí Hārūn al-Rašīd. Tema: Amoroso (gazal) dedicado a tres esclavas de las que estaba enamorado. Metro: kāmil. Rima: ni. $\mathbf{N}^{\mathbf{0}}$ de versos: 3 . Página/s: 122 .

33. Sulaymān b. al-Hakam al-Musta'īn, califa de al-Andalus. Tema: amoroso (gazal) dedicado a tres mujeres de las que estaba enamorado, imitando el poema anterior del califa abasí. Metro: kāmil. Rima: ni. $\mathbf{N}^{\mathbf{0}}$ de versos: 9. Página/s: 122 .

34. Ibn Darrāŷy al-Qasțallī. Tema: panegírico (sultānīya) a Sulaymān alMusta'īn. Metro: țawīl. Rima: nu. $\mathbf{N}^{\mathbf{0}}$ de versos: 53. Página/s: 123-125.

35. Anónimo. Tema: Crítica-sátira (hiŷā’) dirigida a los reyes de taifas. Metro: basīt. Rima: di. $N^{0}$ de versos: 2 . Página/s: 144.

36. Al-Mu'taḍid de Sevilla. Tema: Descriptivo (wașf) sobre un jazmín. Metro: munsariḥ. Rima: ḍu. $\mathbf{N}^{0}$ de versos: 2. Página/s: 157.

37. Al-Mu'taḍid de Sevilla. Tema: Báquico-descriptivo (jamrīya-wașf) sobre una velada nocturna. Metro: țawīl. Rima: qu. $\mathbf{N}^{\mathbf{0}}$ de versos: 2 . Página/s: 157.

38. Ibn 'Ammār de Silves. Tema: Panegírico-elogio (sulțānīya) a al-Mu'tamid de Sevilla pidiéndole perdón y benevolencia por su vida. Metro: țawīl. Rima:

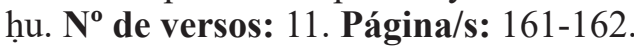

39. Anónimo. Tema: Sapiencial-moral (hikma) sobre la benevolencia y las buenas acciones. Metro: kāmil. Rima: rā. $\mathbf{N}^{\mathbf{0}}$ de versos: 1. Página/s: 162. 
40. Al-Mu'tamid de Sevilla. Tema: Auto-panegírico (sulțānīya) en el que el propio al-Mu'tamid elogia su valentía ante el ataque almorávide. Metro: kāmil. Rima:' $(\varepsilon) . N^{0}$ de versos: 5. Página/s: 163.

41. Al-Mu'tamid de Sevilla. Tema: Auto-elegía (ritāà) escrita por el propio alMu'tamid ante la proximidad de la muerte. Metro: basịt. Rima: di. $\mathbf{N}^{\mathbf{0}}$ de versos: 5. Página/s: 164.

42. Ibn al-Jațīb. Tema: Elegía (ritāà) a al-Mu'tamid cuando visitó su tumba en Agmāt. Metro: basīṭ. Rima: ti. $\mathbf{N}^{\circ}$ de versos: 6. Página/s: 165.

43. Ibn 'Abd al-Ṣamad. Tema: Elegía (ritā̄) a al-Mu'tamid realizada ante su tumba. Metro: kāmil. Rima: di. No de versos: 104. Página/s: 165-170.

44. Anónimo. Tema: Sapiencial (hikma) sobre la supuesta descendencia de alMutawakkil b. Hūd de al-Musta'īn b. Hūd. Metro: wāfir. Rima: ni. $\mathbf{N}^{\mathbf{o}}$ de versos: 3 . Página/s: 176.

45. Ibn Šaraf al-Qayrawānī. Tema: Panegírico (sultānīya) elogiando el origen noble de los afțasíes de Badajoz, supuestamente descendientes de la tribu de Tuŷīb. Metro: sarī'. Rima: r. Nº de versos: 2. Página/s: 182-183.

46. Al-Mutawakkil b. al-Afțas. Tema: Panegírico (ijwānīya) elogiando a su visir Abū Ṭālib b. Gānim. Metro: basīṭ. Rima: na. No de versos: 2. Página/s: 185.

47. Muḥammad b. 'Abdūn. Tema: Elegía (ritāa') a la dinastía de los Banū alAfțas que se acababa de extinguir. Metro: basît. Rima: ri. $\mathbf{N}^{\mathbf{0}}$ de versos: 49 . Página/s: 186-189.

48. Al-Mu'tașim b. Șumādih de Almería. Tema: Sapiencial-consejo (hịma) ante la llegada de malos tiempos. Metro: mutaqārib. Rima: lu. $\mathbf{N}^{\mathbf{o}}$ de versos: 1. Página/s: 191.

49. Ibn 'Ammār de Silves. Tema: Panegírico (sulțānīya) a al-Mu'tașim de Almería. Metro: maŷzū’al-kāmil. Rima: ḥi. No de versos: 3. Página/s: 192.

50. Al-Mu'tașim b. Șumādiḥ de Almería. Tema: Amoroso-nostalgia (gazal) dedicado a Ib́n 'Ammār en respuesta al anterior poema, expresando su tristeza por la separación del poeta. Metro: maŷzū’al-kāmil. Rima: hịi. $\mathbf{N}^{\mathbf{0}}$ de versos: 3. Página/s: 192.

51. Ibn Darrāŷy al-Qasṭallī. Tema: Panegírico (sulțānīya) a Mundir II b. Yaḥyà, señor de Zaragoza. Metro: kāmil. Rima: rā. $\mathbf{N}^{0}$ de versos: 51. Página/s: 198-200. 
52. Abū Ŷa'far b. Sa'dūn. Tema: Panegírico (sultānīya) a Abū Marwān 'Abd al-Malik b. Razīn, señor de Albarracín. Metro: țawīl. Rima: ru. $\mathbf{N}^{\mathbf{0}}$ de versos: 6. Página/s: 207.

53. Abū Marwān 'Abd al-Malik b. Razīn, señor de Albarracín. Tema: Panegírico- elogio (ijwānīya) a Abū Ŷa'far b. Sa'dūn en respuesta al anterior poema. Metro: țawīl. Rima: ru. $\mathbf{N}^{0}$ de versos: 5. Página/s: 207.

54. Abū Marwān 'Abd al-Malik b. Razīn, señor de Albarracín. Tema: Sapiencial- moral (hikma) aconsejando a los que se mofaron por una caída suya del caballo. Metro: basīt. Rima: ru. Nº $^{0}$ dersos: 3. Página/s: 207.

55. Ibn Darrāŷ al-Qasțallī. Tema: Panegírico (sulțānīya) a Jayrān al-fatà, señor de Almería y Murcia. Metro: țawīl. Rima: nu. $\mathbf{N}^{0}$ de versos: 61. Página/s: 212-215.

56. Ibn Darrāŷy al-Qastallī. Tema: Panegírico (sulțānīya) a los fatà-s Mubārak y Muẓaffar, señores de Valencia. Metro: țawīl. Rima: kā. $\mathbf{N}^{0}$ de versos: 48. Página/s: 223-225.

57. Abū Isḥāq al-Ilbīrī. Tema: Sapiencial-moral (hikma) dedicado a Bādīs b. Habūs, señor de Granada, aconsejándole y criticándole (šakwà) por el mal causado por los judíos que estaban al frente de su gobierno, a los cuales satiriza (hiȳā'). Metro: mutaqārib. Rima: īn. Nº de versos: 43. Página/s: 231-233.

58. Joven muchacho anónimo granadino. Tema: Báquico (jamrīya) dedicada a Simāŷa, el cruel primer ministro de 'Abd Allāh b. Buluqqīn, último emir zīrī de Granada. Metro: jafîf. Rima: ḥū. $\mathbf{N}^{0}$ de versos: 3. Página/s: 234.

59. Abū al-Hasan b. al-Ŷadd. Tema: Panegírico (sultānīya) dedicado al emir almorávide Yūsuf b. Tāšufīn. Metro: basīt. Rima: ru. $\mathbf{N}^{\mathbf{o}}$ de versos: 14 . Página/s: 242 .

60. 'Abd al-Ŷalīl b. Wahbūn. Tema: Sapiencial-moral (hikma) dedicado a alMu'tamid de Sevilla, aconsejándole lo mejor para los musulmanes cuando fue a pedir ayuda al emir almorávide Yūsuf b. Tāšufīn contra los cristianos. Metro: basīṭ. Rima: ru. $\mathbf{N}^{0}$ de versos: 6. Página/s: 246.

61. Anónimo. Tema: Sapiencial-moral (hikma) por la caída de la dinastía almorávide en al-Andalus. Metro: wāfir. Rima: h. No de versos: 2. Página/s: 248.

62. Ibn Qasī, rebelde sufí de Mértola y Silves. Tema: Sapiencial-moral (ḥikma) acerca de los meses del año. Metro: țawīl. Rima: li. $\mathbf{N}^{\circ}$ de versos: 2. Página/s: 252.

63. Ibn Qasī, rebelde sufí de Mértola y Silves. Tema: Profético-místico (zuhr) sobre las revelaciones que Dios le da para su gobierno. Metro: kāmil. Rima: h. $\mathbf{N}^{\mathbf{0}}$ de versos: 3 . Página/s: 252. 
64. Abū Bakr b. Ḥubays. Tema: Panegírico-elogio (sulțānīya) al emir de Orihuela Aḥmad b. 'Āṣim. Metro: țawīl. Rima: ru. No de versos: 1. Página/s: 259.

65. Ibn Hamušk, general y suegro de Ibn Mardan̄̌š, emir del Levante. Tema: Sapiencial-gnómico (hikma) acerca de aceptar los designios de Dios. Metro: basīt. Rima: šā. $\mathbf{N}^{0}$ de versos: 2 . Página/s: 263.

66. Abū 'Abd Allāh b. Șāḥib al-Ṣalāt. Tema: Panegírico (sulțānīya) al emir almohade 'Abd al-Mu'min y a los almohades, celebrando su llegada al puerto de Gibraltar. Metro: țawīl. Rima: qu. $N^{0}$ de versos: 2. Página/s: 265-266.

67. Abū 'Abd Allāh al-Ruṣāfī de Valencia. Tema: Panegírico (sulțānīya) al emir almohade 'Abd al-Mu'min y a los almohades, celebrando su llegada al puerto de Gibraltar. Metro: basīṭ. Rima: ri. No de versos: 60. Página/s: 266-268.

68. Ibn al-'Abbār de Valencia. Tema: Panegírico (sultānīya) al emir hafṣ̄ī de Túnez Abū Zakarīyā', solicitando su ayuda ante la inminente pérdida de la ciudad de Valencia contra los cristianos del rey Jaime I de Aragón. Metro: basīt. Rima: sā. Nº de versos: 1. Página/s: 273.

69. Abū al-Mutarrif b. 'Amīra de Valencia. Tema: Elegía (ritā̄) por la pérdida de la ciudad de Valencia. Metro: kāmil. Rima: hu. $\mathbf{N}^{\circ}$ de versos: 20 . Página/s: 273-274.

70. Abū 'Abd Allāh b. Marŷ al-Kuḥl. Tema: Panegírico (sulțānīya) al emir de Levante Ibn Hūd al-Mutawakkil, rival de Ibn al-Ahmmar de Granada. Metro: țawīl. Rima: rā. $\mathbf{N}^{\circ}$ de versos: 10 . Página/s: 278.

71. Anónimo. Tema: Sapiencial-consejo (hikma) sobre el auge y declive de los Estados. Metro: țawīl. Rima: di. No de versos: 1. Página/s: 294.

72. Abū Bakr b. Šīrīn. Tema: Elegía (ritāà) al emir nazarí Muhammad IV. Metro: jafîf. Rima: hu. $\mathbf{N}^{0}$ de versos: 3. Página/s: 298.

73. Anónimo. Tema: Sapiencial-consejo (hikma) sobre las virtudes del gobernante. Metro: kāmil. Rima: mu. $\mathbf{N}^{\mathbf{0}}$ de versos: 2. Página/s: 301.

74. Abū Bakr b. Šīīn ${ }^{13}$. Tema: Elegía (ritāà) al emir nazarí Muhammad IV. Metro: ramal. Rima: ni. No de versos: 63. Página/s: 301-304.

75. Ibn al-Jațīb. Tema: Panegírico (sulțānīya) al sultán meriní Abū Sālim solicitando su ayuda para el emir nazarí exiliado Muḥammad V. Metro: țawīl. Rima: ru. $N^{\mathbf{o}}$ de versos: 28. Página/s: 312-313. 
Una vez vista la lista de piezas poéticas incluida en los A'māl podemos sacar algunas conclusiones y realizar un pequeño análisis de las mismas. Como ya hemos referido al comienzo de este capítulo, todas estas muestras poéticas constituyen una selecta antología de poesía, sobre todo de al-Andalus, que incluye a autores de prácticamente todas las épocas de la dominación islámica en la Península. Así, tenemos a poetas de los primeros siglos, como 'Abd Allāh b. al-Šamir ${ }^{14}$, poeta de la corte de 'Abd al-Raḥmān II, Hāšim b. 'Abd al-'Azīz, visir y poeta de Muḥammad I y de su hijo Mundir, o el famoso Ibn 'Abd Rabbihi, poeta del califa omeya de al-Andalus 'Abd al-Raḥmān III, autor de la obra enciclopédica al-'Iqd al-farīd ${ }^{15}$. Más numerosos son los poetas del final del califato omeya y del periodo de taifas, como Ibn Šuhayd ${ }^{16}$, Ibn Hazm ${ }^{17}$ de Córdoba, Ibn Darrāŷ al-Qasțallī, al-Mu'tamid de Sevilla ${ }^{18}$ y su visir Ibn 'Ammār, Ibn 'Abdūn ${ }^{19}$, Ibn Sa' dūn ${ }^{20}$, Ibn Wahbūn ${ }^{21}$ o Abū Isḥāq alIlbīr $\overline{1}^{22}$. Del periodo almorávide incluye versos del gran poeta de la naturaleza Ibn Jafāŷa ${ }^{23}$, Abū Bakr b. Hubays ${ }^{24}$ y Abū al-Ḥasan b. al-Ŷadd ${ }^{25}$. De la dominación almohade nos presenta versos de poetas como Abū 'Abd Allāh Ibn Șāhịib al-Salāt ${ }^{26}$, Abū 'Abd Allāh Ibn Marŷ al-Kuhl ${ }^{27}$ o del célebre Abū 'Abd Allāh al-Rușāfĩ de Valencia ${ }^{28}$, y sobre todo, destacan al final de gobierno de esta dinastía norteafricana

14 Véase Terés, Elías, "Ibn al-Šamir, poeta astrólogo en la corte de 'Abd al-Raḥmān III" en Al-Andalus, v. 24, $1959,449-463$.

15 Sobre esta obra véase la reciente Tesis Doctoral de Santás De Arcos, Iria, Ibn Qutayba e Ibn 'Abd Rabbihi, 'Uyūn al-ajbār y al 'Iqd al-farīd. Traducción al castellano del Kitāb al-ța' ām y del Kitāb al-farīda al-țāniya fì-lța'ām wa-1-šarāb, Universidad de Salamanca, 2014, bajo la dirección de la profesora Elena Bajo Pérez.

16 Véase Lirola Delgado, J. y Ferrando, I., "Ibn Šuhayd, Abū 'Āmir" en Biblioteca de al-Andalus, v. V, 403-412, y García Gómez, E., Poemas arabigoandaluces, Madrid, 1971, 21 y ss.

17 Célebre poeta, historiador, jurista, filósofo y teólogo cordobés. Nació en el año 384/994 en el seno de una familia de ascendencia cristiana convertida al Islam. Hijo de un visir de la dinastía amirí, fue testigo de excepción de la disgregación del califato omeya por el cual él tomo partido, sirviendo así a los sucesivos aspirantes y califas omeyas, como al-Murtaḍà y 'Abd al-Raḥmān V. Acabó retirándose a Huelva donde impartió lecciones a un pequeño grupo de discípulos. Falleció en el año 456/1064, dejando tras de sí, según su hijo, una producción de 400 obras. Véase Puerta Vílchez, José Miguel y Ramón Guerrero, Rafael, "Ibn Ḥazm, Abū Muḥammad” en Biblioteca de al-Andalus, v. III, 392-443.

18 Véase Rubiera Mata, Mª Jesús, Al-Mu'tamid ibn 'Abbād, Poesías, Madrid, 1982.

19 Véase Monroe, James T., Hispano-Arabic Poetry, Berkeley-University of California, 1974, 228-241 y Nykl, A. R., Hispano-Arabic Poetry and its relations with the old provencal troubadours, Baltimore, 1970, 175-178.

20 Véase Carmona González, A., "Ibn Sa'dūn al-Mulī, Aḥmad” en Biblioteca de al-Andalus, v. V, 58.

${ }_{21}$ Véase Carmona González A., "Ibn Wahbūn al-Mursī, 'Abd al-Ŷalīl”" en Biblioteca de al-Andalus, v. V, 570-573.

22 Véase Penelas, M., "Al-Ilbīrī, Abū Isḥāq" en Biblioteca de al-Andalus, v. VI, 381-384.

23 Véase Sobh, Maḥmūd, Antología poética, Ibn Jafāŷa de Alzira: edición trilingüe, selección, fijación del texto árabe, prólogo y traducción castellana de Mahmud Sobh; traducción al valenciano a partir de la traducción castellana de Josep Piera. Valencia, 1986.

24 Véase "Ibn Hubays, Abū Bakr" en Biblioteca de al-Andalus, v. A, apéndices, 228-229.

25 Véase Marín, Manuela, "Abū Bakr Ibn al-Ŷadd y su familia" en Biografías Almohades, I, Eoba, IX, 223-259.

26 Véase Navarro Oltra, C., "Ibn Ṣāḥib al-Ṣalāt al-Dānī, Abū Muhammad" en Biblioteca de al-Andalus, v. V, 9091.

27 Véase Martín Castellanos, A. J., "Ibn Marŷ al-Kuhl, Abū 'Abd Allāh” en Biblioteca de al-Andalus, v. IV, 119123.

28 Véase Garulo, Teresa, al-Rusafi de Valencia, Poemas Madrid, 1980, especialmente páginas 111-116, Monroe, James T., Hispano-Arabic Poetry, 292-301 y Nykl, A. R., Hispano-Arabic Poetry, 326-327. 
dos grandes literatos y poetas de los cuales nos da una muestra de su poesía, Ibn alAbbār ${ }^{29}$ e Ibn 'Amīra de Valencia ${ }^{30}$.

Finalmente, nuestro autor recoge poemas de autores del periodo nazarí, anteriores y contemporáneos suyos como su maestro Abū Bakr Ibn Šìbrīn ${ }^{31}$, su discípulo y posterior adversario Ibn Zamrak ${ }^{32}$, y por supuesto incorpora poesías suyas, en total tres poemas. También señalar que aparecen poetas de origen no andalusí como Abū al-'Alā' Șā'id b. al-Ḥusayn al-Bagdādī ${ }^{33}$, poeta de los 'āmiríes, o Ibn Šaraf alQayrawānī ${ }^{34}$, poeta de los reyes de taifas.

Ibn al-Jaṭīb incluyó también piezas poéticas de los primeros emires omeyas de al-Andalus, como 'Abd al-Raḥmān I, al-Hakam I, 'Abd Raḥmān II o 'Abd Allāh, a quienes reconocía su talento literario y su capacidad para la composición poética. De esta manera nos dice sobre ellos:

'Abd al-Raḥmān I:

'Abd al-Raḥmān fue un hombre instruido, que llevó una hermosa conducta de moderación... fue autor de numerosas poesías, y eso es sabido. Era 'Abd al-Rahmān b. Mu'àwiya elocuente y bien hablado, instruido, bueno en sus decisiones, dotado para la poesía, destacado entre las gentes de saber. (página 10 del texto árabe).

Al-Ḥakam I:

Al-Hakam, a pesar de su dureza, fue un poeta innato y fue seleccionado de su poesía sus palabras acerca de unas esclavas (ŷawārī) de las que estaba enamorado. (página 17 del texto árabe).

29 Véase Meouak, M., "Ibn al-Abbār, al-Qudā`ī Abū”, en Biblioteca de al-Andalus, v. I, 277-281.

30 Véase Ibn 'Amīra Al-Maḥzūmī, Kitāb tārīḥ Mayūrqa, Crónica árabe de la conquista de Mallorca, ed. y estudio de Muhammad Ben Ma'Mar, Palma de Mallorca, 2009, Velázquez Basanta, F. Nicolás, "Ibn 'Amīra, Abū alMuțarrif” en Biblioteca de al-Andalus, v. II, 445-449 y “Abū (1-) Muṭarrif Aḥmad ibn 'Amīra, epistológrafo y poeta valenciano del siglo XIII a través de la Ihạța de Ben al-Jațî̉”" en Homenaje al profesor Jacinto Bosch Vilá, Granada, 1991, v. I, 393-408, Molina López, E., "Ibn 'Amīra e Ibn al-Ŷannān, fuentes para la historia de al-Andalus en el siglo XIII" en Anales del Colegio Universitario de Almería, 1980, 25-86 y "El gobierno de Zayyān b. Mardan̄̄š en Murcia (1239-1241)" en Miscelánea Medieval Murciana, VII, 1981, 158-188.

31 Véase Rodríguez Figueroa, A., "Ibn Šibrīn, Abū Bakr” en Biblioteca de al-Andalus, v. V, 302-304.

32 Véase García Gómez, Emilio, Ibn Zamrak, el poeta de la Alhambra, Madrid, 1943 y Cinco poetas musulmanes, Madrid, 1975 y Rubiera Mata, Ma Jesús, "Ibn Zamrak, su biógrafo Ibn al-Aḥmar y los poemas epigráficos de la Alhambra" en Al-Andalus, XLII, 1977, 447- 451 e "Ibn Zamrak en Málaga” en Mainake, n 27, 2005, 433-442.

33 Véase Blachère, R., "Un pionnier de la cultura árabe oriental en Espagne au Xème siècle. Șā’id de Bagdad” en Hespèris, X, 1930, 15-36 y Harenska J., “Al-Bagdadī, Șā’id”, Biblioteca de al-Andalus, v. I, 86-89.

34 Véase Veglison, Josefina, La poesía árabe clásica, Madrid, 1997, 240-41 y Lirola Delgado, Pilar, "Ibn Sharaf al-Qayrawan̄i, Abū 'Abd Allāh (abuelo)", Biblioteca de al-Andalus, v. V, 247-255. 


\section{'Abd Raḥmān II:}

Fue un [hombre] elocuente: fueron a verle algunos de sus clientes (mawālì) pidiéndole que emplease su gusto exquisito y su trato delicado. Le dijeron: "No hemos tenido de tu parte ninguna experiencia que remita a ti, ni ninguna prueba que podamos exponerte, salvo lo que hemos visto de tu elocuencia y de tu buena oratoria que ha llegado a nosotros a través de tus epistolas. Y si eres tú su autor, entonces has sido un [hombre] destacado y lo has hecho bien. (Página 19 del texto árabe).

'Abd Allāh:

Estaba el emir 'Abd Allāh dotado para la poesía y la buena escritura. (página 26 del texto árabe).

Como hombre de Estado y poeta cortesano que fue, Ibn al-Jațīb incluyó sobre todo en los A'māl a-a'lām panegíricos de grandes poetas, en especial de la época de taifas, periodo de notable florecimiento cultural y literario, a pesar de la gran fragmentación territorial que aconteció durante el mismo. Las poesías más extensas corresponden a este periodo, pues a pesar de que el polígrafo granadino critica duramente a los gobernantes de este tiempo, por el gran daño que causaron al islam andalusí, no por ello dejó de ser gran admirador de la producción literaria y poética que hubo en sus fastuosas cortes. Entre todos los poetas de esta época destaca uno por encima de todos los demás, Ibn Darrāŷ al-Qasțallīi ${ }^{35}$. Ibn al-Jațīb incluye cuatro poemas de este autor, todos ellos de gran extensión y todos panegíricos. Este poeta cortesano fue el poeta por excelencia de Almanzor, a quien acompañó en sus expediciones militares, dedicándole numerosos elogios. Es raro que Ibn al-Jațīb no incorporase a los A'māl ningún poema de esta época dedicado al dirigente 'āmirí, ya que fue posiblemente el que mejor lo retrató y el que con sus poemas aportó numerosos y valiosísimos datos sobre las expediciones de Almanzor. Posteriormente, Ibn Darrâŷ sirvió a los hijos de Almanzor, al-Muzaffar y Sanchuelo, sobre los cuales tampoco aparecen poemas. Con la caída de la dinastía 'āmirí, compuso panegíricos para los diferentes gobernantes que se sucedieron en el califato, como 'Abd Yabbār al-Mahdī, los distintos dirigentes hammūdíes o Sulaymān al-Musta'īn, sobre el que aparece un largo y clásico panegírico de 53 versos. Más tarde, este poeta se movió por los diferentes reinos de taifas ofreciendo sus servicios, entre ellos el reino de Almería de Jayrān al-fatà, el reino de Valencia de los esclavones Mubārak y Muẓaffar y el reino de Zaragoza de Mundir II b. Yahyà. De todos ellos Ibn al-Jațīb incluye extensos panegíricos compuestos por Ibn Darrāŷ al-Qasțallī.

35 Véase Blachère, R., "La vie et l'oeuvre du poète-épistolier andalou Ibn Darrağ al-Kasțallî̄" en Hespéris, XVI, 1933, pp. 91-121, Alkhalifa, Waleed Saleh, "Ibn Darrāŷ al-Qasțallī, Abu 'Umar", en Biblioteca de al-Andalus: de Ibn Dabbāg a Ibn Kurz, Fundación Ibn Tufayl de Estudios Árabes, Almería, 2004, t. III, pp. 54-59, Viguera Molins, $\mathrm{M}^{\mathrm{a}}$ Jesús, "Versos al triunfo sobre el conde Garci-Fernández" en Al-Andalus, 43, n 2, pp. 467-473, La Chica Garrido, Margarita, "Resumen de Tesis: Almanzor y los poemas de Ibn Darrāy al-Qasțallî”" en Anales de la Universidad de Valencia, nº 134, 1973 e Ibn Darrāŷ Al-Qasțallī, Diwān, ed. Maḥmūd 'Alī Makkī, Beirut, 1969. 
Otros poetas a los que el visir granadino dedicó especial atención, demostrando de esta manera su consideración hacia ellos, fue a las grandes figuras andalusíes, como Ibn 'Ammār, poeta de Silves, que sirvió a al-Mu'tamid de Sevilla y con quien mantuvo una tortuosa relación de amistad. También destaca Ibn 'Abdūn, autor del célebre poema dedicado a la dinastía afțasí de Badajoz con motivo de su desaparición. Este poema fue escrito en un estilo tan oscuro y enrevesado que fue objeto de estudio y explicación en el s. XII por parte de 'Abd al-Malik b. 'Abd Allāh b. Badrūn, en una obra titulada Šarh qasīda Ibn 'Abdūn li-Ibn Badrūn (Explicación del poema de Ibn 'Abdūn por Ibn Badrūn $)^{36}$. Así mismo, hay que señalar a Abū Ishạāq al-Ilbīrī con su célebre casida contra los judío de la Granada de Bādīs b. Habūs s7 , a al-Ruṣāfì de Valencia, que elogió la llegada del califa almohade 'Abd al-Mu'min y a Ibn alAbbār y a Abū al-Muțarrif b. 'Amīra, ambos valencianos y grandes literatos, sobre todo el primero, que lloraron tristemente la pérdida de la ciudad levantina. También es importante hacer especial mención a los dos hermosos cantos elegíacos que Ibn al-Jațīb incluyó sobre la terrible destrucción causada en Córdoba por la sublevación de Muhammad b. 'Abd al-Ŷabbār al-Mahdī. Estas dos magníficas composiciones son obra de Ibn Hazm de Córdoba y de Ibn Šuhayd.

Al igual que hizo con los emires omeyas de al-Andalus, Ibn al-Jaṭîb también fue justo con los distintos reyes de taifas y reconoció sus dotes poéticas, incorporando a los A'māl pequeñas composiciones de varios de ellos, como al-Mu'tadid y al-Mu'tamid de Sevilla, al-Mutawakkil b. al-Afțas de Badajoz, al-Mu'tașim b. Șumādih de Almería o Abū Marwān 'Abd al-Malik b. Razīn de Albarracín. Todos ellos, y otros más, gustaron de rodearse de poetas y sabios a los que agasajaron en sus cortes, creando importantes círculos culturales a su alrededor, motivo por el cual fueron elogiados por el propio Ibn al-Jatị̂b.

A lo largo de todo el Kitāb A'māl al-a'lām Ibn al-Jațīb hace referencia a los poetas, a su posición en las cortes, a la mala situación que vivieron con la sublevación de Muhammad b. 'Abd al-Ŷabbār al-Mahdī y Sulaymān al-Musta'īn, realza a los que él considera que están por encima de los demás y elogia a los emires, reyes o sultanes que fueron dotados de sensibilidad poética.

Veamos algunas de estas referencias en el Kitāb A'mal al-a'lām:

Sobre al-Mundir, emir omeya de al-Andalus:

36 Esta obra fue editada por Dozy, R. P., Commentaire historique sur le poême d'Ibn Abdoun par Ibn Badroun, Leyde, 1846.

37 Este poema aparece editado en árabe, con análisis y notas por García Gómez, Emilio, Un alfaquí español Abū Ishāa de Elvira, Madrid-Granada, 1944, 149-154 y varios de sus versos aparecen traducidos al español en Pérès, H., Esplendor de al-Andalus, 113, 246 y 277. También fue estudiado y traducido por Dozy, R. en Historia de los musulmanes de España. Los reyes de taifas, 99-102. Asimismo Maíllo Salgado, F., "Los judíos en las fuentes andalusíes y magrebíes: Los visires", en Studia historica. Historia medieval, vol. 23, 2005, 221-249, en el Apéndice III, 239-240, da traducción española de la casida de Abū Ishāā, según el texto editado por Monroe, J. T., Hispanic Poetry, Berkeley, 1974, 207-213, que se valió de dos fuentes para completarlo y señalar variantes, a saber: la edición citada de García Gómez, E, y aquella otra de Nykl, A. R., Makhtarāt min ash-shi'r al-andalusī, Beirut, 1949, 141-143. 
Colmó de presentes a los poetas, que lo ensalzaban como conquistador y [hombre] excelente. Estaban entre sus poetas Ahmad b. 'Abd Rabbihi, al- 'Akki ${ }^{38}, y$ otros poetas árabes. (Página 23 del texto árabe).

Acerca de Ibrāhīm b. Haŷŷāŷ, rebelde de Sevilla durante la época del emir omeya 'Abd Allāh y del califa 'Abd al-Raḥmān III:

Emulaba a los reyes, los poetas se dirigían a su corte y las gentes nobles tenían puestas sus esperanzas en él. Y sobre él dijo Ibn 'Abd Rabbihi en una casida cuyo primer verso es:

\section{[Metro wāfir]}

1) La carta del amor apasionado está envuelta por su corazón, y de las lágrimas profusas obtiene él la tinta. (Página 35 del texto árabe)

Sobre Sulaymān al-Musta'īn, califa de al-Andalus tras la caída de los 'āmiríes:

Fue [Sulaymān] literato y poeta, sensato y reflexivo, sin embargo [su] gobierno [acabó] recordándose por sus mentiras. Su poesía fue trasmitida y conocida. Es uno de los que ennoblecieron la poesía con su nombre y [la] sometieron a su criterio. Entre lo más célebre de él, están [estas] palabras [en las] que imita a las de al-Rašĭd Hārūn ${ }^{39}$ con motivo de sus tres esclavas ( $\hat{y} a w a \bar{r} \bar{\imath})$ :

Los poetas gozaron de una situación desahogada durante el emirato y el califato de los omeyas y durante la regencia de Almanzor y sus descendientes. Sin embargo, la secesión que siguió al levantamiento de Ibn 'Abd al-Ŷabbār al-Mahdī fue nefasta para ellos:

...Disfrutaron [de todo esto] los poetas amiries y de la dinastía omeya. [Sin embargo] las arañas tejieron [sus telarañas] sobre sus bocas y mihrāb-s durante los días de la guerra y la secesión. Su miseria [la de los poetas] se intensificó y su carácter se irritó. Eran como halcones (buzāt) solos y hambrientos que se lanzan en picado sobre los saltamontes a causa de la extrema necesidad. No prestó atención [Sulaymān] a su intensa sed, ni cubrió sus necesidades, por [que] estaba preocupado por su situación y la agudización de la miseria de su reino.

(Página 123 del texto árabe).

38 Se trata de Muḥammad b. 'Awf al-'Akkī, natural de Reyyo, además de hombre sabio y literato, ejerció como jefe de la oración en Córdoba nombrado por el emir Muḥammad I. Ejerció también como muftí en su localidad natal, experto en ra'y y trasmisor del Corán. Véase Castilla Brazales, Juan, "Ibn Abī Dulaym: aclaraciones en torno a una šuhra" en Estudios Onomástico-biográficos de al-Andalus, v. VI, CSIC-Madrid, 1994, 157 y Fierro, Maribel y Marín, Manuela, "La islamización de las ciudades andalusíes a través de sus ulemas (s. II/VIII- comienzos s. IV/X)" en Genèse de la ville islamique en al-Andalus et au Maghreb occidental, Casa de VelázquezCSIC, Madrid, 1998, 93-94 y Marín, Manuela, "Nómina de sabios de al-Andalus (93-350/711-961)" en Estudios Onomástico-biográficos de al-Andalus, v. I, Madrid, 1988, nº 1287, 1052.

39 Quinto califa abasí (170/786-193/809). Véase Bosworth, C.E., the Islamic Dynasties, Edinburgh, 1980, 7-10. 
Como ya hemos mencionado, Ibn al-Jațî̉ incorpora en los A'māl cuatro extensos poemas de Ibn Darrāŷ al-Qasțallī, demostrando con ello el gran respeto y admiración que le profesaba, dedicándole palabras de elogio, como:

$Y$ acerca de ello recitó el poeta de al-Andalus de aquella época, Abū 'Umar b. Darrāŷa al-Qastallī, que se encontraba allí y que estaba en aquel entonces al [mismo] nivel que al-Mutannabi ${ }^{40}$ de Siria. (Página 123 del texto árabe).

El poderoso rey al-Mu'taḍid de Sevilla fue también elogiado por Ibn al-Jațīb:

Se dedicó a las bellas letras con la más inmediata consideración y la más penetrante disposición, [de tal manera] que obtuvo de ellas una parte considerable... Al-Mu'tadid, además de su generosidad, valentía y elevadas miras, componía versos y de él proceden pequeñas y hermosas composiciones y sublimes conceptos. $Y$ de las poesías a él atribuidas [están] sus palabras:

\section{[Metro munsarih]}

Es como si nuestro fresco jazmín

fuera una estrella que en el cielo resplandece.

Y los pliegues rojizos en sus costados

son como la mejilla de una virgen que ha sido mordida.

(Páginas 155 y 157 del texto árabe).

También reconoció el talento poético de su hijo al-Mu'tamid:

[Fue] único en elocuencia, pródigo en la poesía y la escritura, excelente en el verso y la prosa, educado, fecundo en palabras, prolifico en ideas, libre de plagios, suave en los giros de palabra, fino en la glosa, denso de contenido, rico en recursos estilísticos, de hermoso estilo, acertado en la metáfora, bueno en la alusión y copioso en la invención de neologismos. No recitó nadie entre los visires y los poetas mejores versos que los suyos, a pesar de la abundancia de panegíricos que le llevaron, de las numerosas perlas de elogio que sobre él se esparcieron y de los múltiples y bondadosos poemas que fueron colocados en sus manos."(Página 157 del texto árabe).

La poesía de Ibn 'Ammār de Silves, visir de al-Mu'tamid, fue muy elogiada y valorada a lo largo de las épocas, y casi logra salvarle la vida a pesar de la gran traición que cometió contra su señor, lo que nos demuestra el poder y la importancia que tenía la poesía cortesana:

40 Poeta oriental de corte neoclásico. Ha sido considerado el mayor poeta árabe de todos los tiempos. Nació en Kufa (302/915), hombre ambicioso y sin escrúpulos que llegó a hacerse pasar por profeta, de ahí su apodo, alMutanabbī (el que se hace pasar por profeta). Estuvo un par de años en la cárcel para pasar después a servir en Alepo al príncipe hamdaní Sayf al-Dawla, donde sus poesías fueron bien recibidas, reportándole mucho dinero. Después, una disputa le hizo salir de Alepo hacia Egipto y más tarde a Iraq y Persia, falleciendo en su regreso a Bagdad (354/965), al ser atacado por un grupo de beduinos. Véase Vernet, Juan, Literatura árabe, Barcelona, 2002, 108-111, Veglison, Josefina, La Poesía árabe clásica, Madrid, 1997, 183-192 y García Gómez, Emilio, Cinco poetas musulmanes, Madrid, 1944, 16-65. 
Hubo en las poesías de Ibn 'Ammār, con el propósito de pedir la ayuda y la benevolencia de [al-Mu'tamid], palabras célebres que hubieran curado con su anhelo la herida de los corazones, y hubieran hecho desaparecer las montañas de agravios, si no hubiese sido porque el destino escrito y el fin establecido habian llegado a su final. (Página 161 del texto árabe).

Ibn al-Jaṭīb también nos habla del talento del rey de Badajoz al-Muẓaffar b. al-Afțas, de su corte de poetas y de sus gustos poéticos:

Era un hombre erudito, sabio...Suya es la gran obra llamada al-Muzaffarī de aproximadamente cincuenta volúmenes...Rechazaba la poesía de [los autores] que escribían en su tiempo y menospreciaba la opinión de aquellos que formaban parte de su diwān ${ }^{41}$ diciendo: ";Aquel cuya poesía no sea como la poesía de al-Mutannabī o al-Ma'arrī, que se calle!’. Solamente le agradaba esa [poesía]. (Páginas 183-184 del texto árabe).

Y sobre todo elogia a su hijo 'Umar al-Mutawakkil:

Fue al-Mutawakkil un rey poderoso, de virtud reconocida, un ejemplo de grandeza y magnanimidad, que [formaba parte] de las personas de discernimiento, firmeza y elocuencia. Fue la ciudad de Badajoz durante su reinado la morada de las bellas letras (adab), la poesía, la gramática y la ciencia ('ilm).

Dijo al-Fatḥ [b. al-Jāqān] en su [Kitāb] Qalā ìd [al-'iqyān] al hacer mención de él: Dominó el ejército de la escritura y el de los soldados, enarboló los estandartes y los pendones, ordenó a [sus] días y [éstos] le obedecieron; las esperanzas daban vueltas alrededor de su Caaba y [la] visitaban en peregrinación, [siendo] un hombre elocuente y locuaz, generoso y cordial con el que iba a visitar[le], [autor] de una poesía que deja en mal lugar a las [más] engastadas perlas, y de una prosa que fluye con la delicadeza del céfiro. [Gobernó durante] unos días tan hermosos que parecian semanas, y [durante] unas noches en las que los hombres se reunian y se encontraban. (Página 185 del texto árabe).

Muḥammad b. 'Abdūn fue poeta y visir de al-Mutawakkil y lo elogió componiendo un oscuro y complicado poema en su honor:

El visir Abū Muhammad Ibn 'Abdūn, hombre importante de su reino y poeta de sus veladas, lloró su pérdida con un poema en el que recoge todo rey que fue asesinado, y hace referencia a quien de ellos fue engañado y traicionado, [para] que quienes la oigan consideren su importancia y extraigan una lección de ella. (Página 186 del texto árabe).

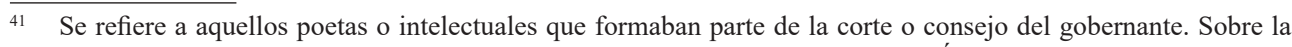
polisemia de esta palabra véase Maíllo Salgado, Felipe, Diccionario de Historia Árabe e Islámica, Madrid, 2013, sub voce "dīwān". 
Ibn al-Jațîb era más que consciente de que la poesía no sólo tiene un valor estético, la belleza en sí misma, sino que es fuente de datos y lecciones, y en relación con el anterior poema de Ibn 'Abdūn nos dice:

Hemos consignado por escrito este poema (qașìda) por ser conveniente para el interés de la Historia. (Página 189 del texto árabe).

Al-Mu'tașim b. Șumādih de Almería se rodeó también en su corte de poetas y compuso sus propias poesías. Entre sus poetas se contaba también a Ibn 'Ammār:

Ibn 'Ammār fue durante largo tiempo huésped de [al-Mu'tașim], y [en cuya corte] fue copiosamente bañado por [la generosidad] de las nubes de sus manos. (Página 192 del texto árabe).

Mundir b. Yahyyà, señor de Zaragoza, a comienzos de la fitna estableció también a su alrededor un séquito de poetas a los que retribuyó en abundancia:

Fue generoso: dio a quienes se dirigían hacia él grandes haberes; entonces llegaron [muchos] a él y por ello su capital, Zaragoza, prosperó. Sus días fueron buenos y los panegiristas alabaron su recuerdo. (Página 196 del texto árabe).

Igualmente su nieto Mundir II b. Yahyà mantuvo su afición por los poetas y literatos:

Tuvo varios secretarios ilustres, y a él se dirigieron los mayores poetas. Sobre él escribió una poesía Abū 'Amr Ibn Darrāŷy [al-Qasțallī], cuando se dirigió hacia su corte y se presentó delante de él en el año 428 [25 de octubre de 1036 a 13 de octubre de 1037]. (Página 198 del texto árabe).

Muŷāhid al-'Āmirī, señor de Denia y de las Islas Baleares, buscó con ahínco el conocimiento, y aunque gustó de la poesía y de los poetas, se rodeó sobre todo de ulemas y alfaquíes:

Abū al-Ŷyaš Muȳāhid difería del resto de los reyes de su tiempo por sus excelentes conocimientos, entre los más destacados [estaba]: la ciencia ('ilm) y el saber (ma'rifa), en las cuales no hubo entre los hombres libres (ahrār) ni entre los clientes (mawālī), nadie más ilustre que él, [hasta el punto de] sobrepasar a los expertos en ellas, los grandes ulemas de su tiempo, sobre todo en lo referente a las ciencias del lenguaje. Profundizó en ellas hasta dominar [también] las ciencias del Corán: su lectura, sus sentidos ocultos, sus términos oscuros y su interpretación. Se interesó por la búsqueda de [todo] eso desde su juventud hasta su madurez, llegando en ello al máximo conocimiento. Reunió [en lo concerniente a] libros lo que no habia reunido nunca [antes] ninguno de sus semejantes. Acudieron a él ulemas de todas partes, y se reunieron en sus patios un grupo de sus jeques y de los [más] ilustres de sus generaciones.(Página 218 del texto árabe). 
Y sobre su pasión por la poesía nos dice:

Fue [Muŷāhid], además de su cultura (adab) y ciencia ('ilm), el más sobrio de los emires en cuanto a la poesía, y el más exigente en su recitación, que no cesaba de reprender con su crítica, descubriendo un [fallo] en la pronunciación, un equívoco, un plagio o una insensatez. Por ello, los poetas se abstuvieron [de alabarlo]. (Página 219 del texto árabe).

A la corte de los esclavones de Valencia Mubārak y Muzaffar acudían desde Córdoba los intelectuales en busca de su generosidad y protección:

Se unieron a estos dos arráeces un [grupo] de elocuentes y virtuosos secretarios de la capital que habian pasado estrecheces a causa de la guerra civil, por la sólida seguridad que imperaba en su reino. [Entre ellos estaba] Ibn al-Tākurunnī, Ibn Muhallab e Ibn Tāautut. Colocaron a [estos hombres] en su gobierno en el [mismo] puesto que el de los jeques visires de Córdoba. [Muzaffar y Mubārak] acudian a ellos para [pedirles] opinión, consejo y medidas."(Página 225 del texto árabe).

'Abd Allāh b. Buluqqīn, el último rey zīrī de Granada, también cultivó la poesía y fue frecuentado por poetas:

Granada estaba por aquel entonces repleta de notables, hombres eminentes del islam, guerreros y literatos... Fue [un hombre] que escribió, cultivó la poesía y habló de [todo] aquello de lo que hablan los estudiosos. (Páginas 234-235 del texto árabe).

El pequeño rebelde de Orihuela, Aḥmad b. 'Āṣim, que se sublevó aprovechando la debilidad del gobierno almorávide al final de sus días, fue un hombre instruido que formó una corte literaria a su alrededor:

Él es Aḥmad b. 'Abd al-Raḥmān b. 'Alī b. 'Abd al-'Azīz b. Sa'ìd b. 'Āṣim, uno de los estimados arráeces de [al-Andalus], dueño de una ilustre ascendencia y nobleza, que estuvo [al frente] del cadiazgo [primero], y luego del poder (imāra). Se hizo con la jefatura de su ciudad, [Orihuela], durante la mencionada época. La gente le compuso poemas (casidas), lo alabaron y elogiaron como se muestra en la poesía de Abū Bakr b. Hubays (Página 259 del texto árabe).

Al igual que Ibn 'Āṣim de Orihuela, en Guadix se proclamó independiente durante un tiempo Aḥmad b. Milhạn que buscó emular a los grandes reyes de taifas:

Tuvo a su servicio a un grupo de célebres hombres de ciencia y letras, como Abū Bakr Ibn Tufayl y Abū al-Hakam Harūdus.

Con la caída del imperio almorávide en al-Andalus, sus gentes pidieron la llegada de los Almohades para que acabasen con la situación de desorden y anarquía reinante. Los poetas salieron a recibir a su nuevo califa, 'Abd al-Mu'min, a su llegada a Gibraltar para alabar sus virtudes y granjearse su mecenazgo: 
Cuando 'Abd al-Mu'min b. 'Alī puso bajo su obediencia a la mayor parte de las comarcas andalusies de la región occidental: Sevilla, Jerez y Huelva, se puso en marcha hacia al-Andalus en [el mes] de dū al-qa'da del año 555 [2 de noviembre a 1 de diciembre de 1160]. Se instaló en Gibraltar en el mes mencionado. Se presentaron ante él las gentes de al-Andalus y los poetas le recitaron [casidas]. Acerca de esto dijo Abū 'Abd Allāh Ibn Șāhịb al-Salāt...y sobre esto recitó Abū 'Abd Allāh Ibn al-Rușāfì, el poeta de al-Andalus en su tiempo, su célebre casida en la que describe Gibraltar. (Páginas 265-266 del texto árabe).

Al final del periodo almohade en al-Andalus se hizo con el poder de la isla de Menorca Sa'īd b. Hakam al-Amawī ${ }^{42}$, que desempeñaba el cargo de almojarife.

Buscó, al igual que otros pequeños reyes, rodearse de sabios y literatos:

Fue un hombre ambicioso, que se atrajo a las gentes de ciencia (ulemas), los colmó de favores y rescató a quién de ellos cayó en manos del enemigo. Fue un hombre tremendamente versado en la transmisión del hadīt, dotado para la composición poética y la buena escritura... Duró en Menorca el gobierno de [Ibn Hakam], el cual fue el objetivo de hombres distinguidos y literatos, según se desprende de la correspondencia oficial de Abū al-Muțarrif [b. 'Amīra], de Ibn al-Ŷannān y de otros, aproximadamente cincuenta años, hasta que falleció en el año 680 [22 de abril de 1281 a 10 de abril de 1282]. Heredó la jefatura después de él su hijo Abū 'Umar. (Páginas 275-276 del texto árabe).

Ibn al-Jațīb, antes de comenzar el capítulo dedicado a los nazaríes, se lamenta grandemente por todas las ciudades perdidas por el islam andalusí y hace un sentido elogio de al-Andalus, incluyendo dentro de su patrimonio material la poesía y la prosa de los autores andalusíes, testimonios de la grandeza de su patria:

Y quien crea que este país andalusí, el cual el enemigo [cristiano] ha rodeado, destrozado y estrechado, es como otros países de la tierra en belleza, esplendor, desahogo, prosperidad, construcciones, inexpugnabilidad, hombres, animales, talante, carácter, costumbres, presencia, mérito, conocimiento, artes, maestría, valentía, vigor, elegancia y finura, entonces [quien piense eso] habrá agraviado sus derechos y menospreciado su [auténtico] valor. ;Y lo que da testimonio [de esto] son [sus] dones y [sus] escritos, y las categorías de [sus] ulemas que fueron registradas, y los lugares de [sus] combates que fueron mencionados, y su poesía y su prosa que fueron compiladas! (Página 293 del texto árabe).

42 Véase Molina López, Emilio, "El gobierno independiente de Menorca y sus relaciones con al-Andalus e Ifriqīy. "El Kitāb Lubāb al-albāb", una nueva fuente para la historia del Occidente musulman", Revista de Menorca, n 73, 1982, 5-88; Rubiera Mata, M M Jesús, "La corte literaria de Ibn Sa'îd de Menorca (S. XIII)", Revista de Menorca, $n^{\circ}$ 75, 1984, 105-138 y "El poeta Ibn al-Labbana de Denia en Mallorca», Boletín de la Sociedad Arqueológica Luliana, Palma, XXXIX, 503-511. 


\section{Temas y Métrica}

Antes de finalizar con este repaso a la poesía contenida en el Kitāb A'māl al-a'lām, me gustaría hacer una breve mención al aspecto formal de estas composiciones, a sus temas y a la métrica. En principio resulta difícil llevar a cabo un análisis exhaustivo de estas piezas poéticas, ya que algunas de ellas están incompletas o bien simplemente se trata de trozos o fragmentos de poesías mucho más largas, que Ibn al-Jațīb decidió incluir para darnos una muestra de la destreza y habilidad poética de su autor. A pesar de ello, no resulta difícil, sobre todo analizando los poemas más largos, afirmar que la mayoría de las poesías siguen una estructura formal de corte clásico, con una introducción que normalmente es amorosa (nasīb), pero también puede ser sapiencial (hịma) o báquica (jamrīya), seguida a veces de una descripción del viaje del poeta o del personaje elogiado (rahịl), para después abordar el tema central de la poesía, el elogio (madīḥ) y en menor grado la sátira (hiŷā'). En ocasiones aparecen poemas extraídos de esta estructura y se aborda directamente el tema en cuestión. Así hay poemas que son todo él un panegírico, un poema báquico, sapiencial, ascético, descriptivo o amoroso.

A pesar de la gran selección de poesía que Ibn al-Jațīb nos ofrece en esta obra, parece claro que no puede apartar sus gustos personales y los propios de los literatos de la época nazarí, de tal manera que el tema central de la mayoría de los poemas es el panegírico o elogio, tema fundamental de la poesía árabe, pero más todavía, si cabe, del periodo nazarí. Eso es así, principalmente, porque a lo largo de la historia, y en especial durante el periodo de vida de Ibn al-Jațīb, los poemas que se componían eran de tipo cortesano, donde el poeta generalmente dependía del sultán o el señor local que le mantenía, y nuestro autor, cronista oficial de la dinastía granadina y hombre de corte por excelencia, no fue una excepción en estas lides. Podría decirse que el elogio y la alabanza formaban parte innata del espíritu árabe.

Dentro del panegírico, las poesías presentes en esta obra pueden dividirse en dos grupos: Las casidas sulțānīyas, que son la mayoría, en alabanza al califa, emir o rey, y en menor medida, las casidas ijwānīyas, en elogio de un amigo o de algún personaje de la corte, o también para felicitar por el nacimiento de un hijo, agradecer un regalo o bien ofrecer un presente, como el cervatillo que el poeta Șā'id b. al-Ḥasan al-Bagdādī regaló a Almanzor. Después del panegírico los temas más tratados son: El amoroso (gazal), en el cual la mayoría de los poemas que incluye Ibn al-Jațîb se refieren a la ausencia o nostalgia del ser amado que impide la plena realización del deseo amoroso, lo que hace que el poeta se queje por un amor insatisfecho. También en ocasiones, en relación con el género amoroso, aparece el tema de la nostalgia o separación, con un lugar o un tiempo pasado, como es el caso de la destrucción y pérdida de la ciudad de Córdoba, llorada por Ibn Ḥazm e Ibn Šuhayd, o cuando 'Abd al-Raḥmān I recuerda su patria al ver una palmera en la almunia de al-Rușāfa de Córdoba: "(Metro țawīl): 
Aparece ante nosotros en medio de la Rușāfa una palmera, que se encuentra lejos de la patria de las palmeras, en la tierra de Occidente.

Y yo digo:[ella] es como yo, exiliado y en la distancia, separado de mis hijos y de mi familia.

Brotas en una tierra en la que eres una extraña, Y tú al igual que yo, estás apartada [de tu patria], en un lugar lejano.

Del mismo modo aparece el tema de la elegía (ritā̄) dedicado casi siempre a la muerte de un emir, califa, rey de taifas o también una ciudad, como es el caso de Córdoba y Valencia, sobresaliendo la elegía que Ibn al-Jatị̂b dedica a al-Mu'tamid de Sevilla cuando visitó su tumba en Agmāt en el año 762/1361. Igualmente, aparece también en varias poesías el tema sapiencial o gnómico (hikma), en el que el poeta básicamente da consejos con un carácter moral, como el alejarse de los placeres y las comodidades, acercarse a Dios, seguir una conducta de honradez y compasión y buscar la sabiduría, instruye sobre la brevedad de la vida y la muerte, y sobre todo da consejos acerca del gobierno y la política. Este tema era muy del gusto de nuestro autor, un verdadero ideólogo sobre el arte de gobernar. Destaca en especial una poesía suya en la que se queja contra sus opositores de la corte y del pueblo, contrarios a los cargos que desempeñaba en el gobierno nazarí, y da una lección de cómo debe guiarse un verdadero líder y hombre de Estado.

En menor medida aparecen poemas o fragmentos de poemas de tema descriptivo (wașf), como el poema de Ibn Jafāŷa en el que describe a al-Andalus como un paraíso, de tema báquico (jamrīya), como el poema del joven muchacho que recita a Simāŷa, el cruel visir zīrī de Granada, de tema ascético (zuhrīya), como el del rebelde de Mértola Ibn Qas̄̄, o de tema satírico (hiŷā'), como el poema de Ibn Zamrak en el que se burla del cadí de Granada al-Nubāhī.

En cuanto a la métrica de los 75 poemas o piezas poéticas contenidas en los A'māl, hemos constatado un claro predominio del metro tawīl, en un total de 22 poemas, lo que supone un $29,3 \%$ con respecto al resto de los otros metros. A continuación siguen en importancia el kāmil, 16 poemas $(21,3 \%)$, basīt, 14 poemas $(18$, $6 \%)$, jafîf, 7 poemas $(9,3 \%)$, el wāfir, 5 poemas $(6,6 \%)$, mutaqārib, 3 poemas (4\%), maŷzū al-kāmil, 2 poemas $(2,6 \%)$, y con un poema (1,3\%) los metros sarī', ramal, munsarih, maŷzū’al-jafîf y mujalla' al-basīṭ.

Si comparamos nuestros resultados con los principales estudios de métrica realizados desde mediados del siglo XX hasta nuestra fecha, podemos ver que los resultados son muy similares. Nos basaremos principalmente en los datos aportados en los dos trabajos realizados sobre métrica por la profesora Celia del Moral, "Notas para un estudio de la poesía árabe-granadina” en Meah, v. 32-33, 1983-1984, pp. 55-94 y "Aportación al estudio de la métrica árabe a través del Dīwān de Ibn al-Jațīb y de otros poetas del reino nazarí” en Meah, v. 37, 1988, pp. 183-194. A su vez, emplearemos el realizado por Khalid Chakor Alami, "Contribution a l'étude de la métrique árabe dans la poésie Nașride du XIV siècle” en Meah, v. 47, 1998, pp. 89111, trabajo que complementa a los anteriores de Celia del Moral, pero no por ello menos sustancial. 
En estos estudios, la profesora Celia del Moral compara sus resultados con los de otros importantes y pioneros en la métrica. Expondremos a continuación dichos trabajos y los resultados a los que llegaron:

1. El primero de los estudios en antigüedad es el de E. Bräunlich, "Literargeschichtliche betrachtungsweise altarabischen poesien" en Der Islam, $\mathrm{n}^{\circ}$ 24, 1937, pp. 201-269. En él su autor analiza la poesía de los siglos VI y VII d. cC., es decir la poesía preislámica y del siglo I de la Hégira. Su autor señala un claro predominio del metro țawīl, un 36, $10 \%$, le sigue el metro wāfir, un 16, $82 \%$, luego el basīt con un 13,05\%, kāmil con un 11,36 \% y mutaqārib con un 6,24 $\%$. Estos son los cinco primeros versos de mayor porcentaje. A continuación vienen el raŷaz, sarī', jafîf, ramal, munsarih y madīd, con un porcentaje inferior al $3 \%$.

2. El segundo es el de J. Vadet, "Contribution à l'histoire de la métrique árabe" en Arabica, v. II, 1955, pp. 313-321. Este trabajo analizó la poesía de los siglos VIII-X/I-III, sobre todo del siglo II de la Hégira, e indica un predominio del metro țawīl, un $19,8 \%$, basìt, con un $13,5 \%$, kāmil con un $11,5 \%$, sarī', con un $9,8 \%$ y wāfir con un $8,9 \%$ en el grupo de los cinco primeros metros. Le siguen el jafif, munsarih, aparecen también los metros modificados, maŷzū' al-kāmil, maŷzū’ al-ramal, siguen el ramal, raŷaz, hạaŷ, mutaqārib, madīd y muŷtatt.

3. El tercer estudio es el de Ŷamal Eddine Bencheikh que se encuentra en los capítulos IX y X de su libro Poétique Arabe. Essai sur les voies d'une création, Paris, 1975. Éste, que se basó en la poesía del siglo IX/III, sitúa en primer lugar al metro kāmil, con un 20, 92\%, seguido del țawīl, con un 18, $80 \%$, el basịt con un $15,76 \%$, jafïf con un 10,76\% y wāfir con un 9,63\%. Luego, en menor medida vienen el metro sarī', munsarih, mutaqārib, ramal, raŷaz, hazayy, maŷzū’al-ramal, maŷzū’al-kāmil y muŷtatt. En último lugar vendrían el madīd, maŷzū’al-raŷaz, maŷzū’al-wāfir y maŷzū’al-mutaqārib.

4. El cuarto es el realizado por Celia del Moral en los dos artículos antes citados. En ellos, sobre todo en "Aportación al estudio de la métrica árabe a través del Dīwān de Ibn al-Jațīb y de otros poetas del reino nazarí”, analiza la poesía del periodo nazarí de los siglos XIII-XV d. cC., incluyendo los divanes dīwāns de tres grandes figuras del reino nazarí, como son Ibn Jātima, Ibn al-Ŷayyāb e Ibn al-Jatịib. La autora nos indica que, sobre un total de 978 piezas poéticas, se observa un claro predominio del metro țawīl con un 30,06\%, le sigue el kāmil con un $20,34 \%$, basit con un $14,51 \%$, jafíf con un $7,36 \%$, sarī' con un $6,33 \%$ y wāfir con un $5,31 \%$. Después vendría el metro mutaqārib con un $4,60 \%$, ramal con un $4,08 \%$, munsarih con un $2,65 \%$, raŷaz con un $1,53 \%$ y muytatt con un $1,02 \%$. Finalmente por debajo del $1 \%$ estarían el metro madīd, mujalla' al-basīṭ, mutadārik, maŷzū’ al-kāmil, maŷzū’ al-ramal, maŷzū’ al-jafîf, ḥazaŷ, mutaqārib-kāmil, muḍāri' y muqtadab. 
5. El quinto y último es el realizado por Khalid Chakor Alami en el artículo antes mencionado. Este investigador analizó la producción poética de nueve poetas del periodo nazarí del siglo XIV que dividió en tres generaciones: Lla primera generación está formada por Ibn al-Ŷayyāb, al-Šarīf al-Garnāțī, Abū al-Barakāt al-Balafìqī e Ibn Hudayl. La segunda generación es la de Ibn alJațīb, Ibn al-Haŷŷ al-Numayrī e Ibn Jātima. La tercera generación es la compuesta por Ibn Zamrak y 'Abd Allā Ibn Ŷuzayy. Los resultados a los que llegó después del análisis de la producción poética de las tres generaciones, fue que había un predominio claro del metro țawīl, con un $29,77 \%$, seguido del kāmil con un $22,84 \%$, basīt con un $11,32 \%$, jafíf con un $7,59 \%$ y sarī' con un $7,46 \%$.

Si comparamos nuestros resultados con los de estos trabajos, observamos que el grupo formado por los cinco-seis primeros metros es prácticamente igual al de todos los estudios. En todos, menos en el estudio de Bencheikh, el metro dominante es el țawīl. En segundo y tercer lugar vendría el metro kāmil y el metro basịṭ, y a continuación los metros jafîf, sarī'y wāfir. La posición y el porcentaje de estos últimos metros varía según los estudios, pero siempre están dentro del grupo de los cincoseis primeros metros más frecuentes.

\section{Conclusión}

En definitiva, se puede decir, siguiendo los estudios de Celia del Moral y Khalid Chakor Alami, que la poesía árabe clásica desde sus comienzos ha sido presa de su propia forma, y aunque se han producido ligeras novedades e innovaciones formales y temáticas, la poesía ha estado sometida a los férreos moldes de los antiguos metros que alcanzaron su plenitud de una manera temprana. A lo largo de más de diez siglos esta métrica se ha repetido sin cambios importantes y no se ha producido una evolución de consideración que cabría suponer en un periodo de tiempo tan prolongado. Los poetas no se aventuraban a jugar con la estructura del arte poético, que consideraban casi sagrado, sobre todo cuando se trataba de poesías de carácter oficial, dedicadas a sultanes, califas y mecenas. Seguramente, para el poeta de corte lo más importante era conseguir fama y éxito, mucho más que buscar innovaciones métricas o formales, y sabía que el camino más rápido y seguro a ese éxito era siguiendo un modelo ya establecido, y sobre todo aceptado. No obstante, hay que decir también que cuando el poeta árabe componía en otras formas poéticas no oficiales y fuera de la poesía clásica, como la moaxaja (muwaššaḥ) o el zéjel (zaŷal), la innovación métrica y formal se podía realizar con mucha más libertad.

Todas estas consideraciones han hecho que los investigadores se planteen preguntas como: ¿A qué se debe este hecho? ¿Cuál ha sido la evolución de la métrica árabe desde sus orígenes? ¿Cuál era el ánimo del poeta al componer en tal o cual metro o rima? ¿Se utilizan determinados metros para determinados temas y ocasiones o es algo circunstancial? La respuesta a todas estas preguntas es compleja y requiere de la realización de más e importantes estudios sobre la poesía árabe de todas las épocas para confrontar los resultados y extraer hipótesis razonables y científicas. 
Sí podemos decir, nuevamente apoyándonos en los trabajos antes citados, que no existe una estrecha relación entre el metro empleado y el tema del poema. Lo que sí parece evidente es que ciertos metros se prestan mejor a determinados temas por su ritmo pausado o acelerado, lo que puede ser empleado para generar calma o bien una emoción más viva, pero no puede asegurarse que exista una auténtica relación entre ambos elementos. De esta manera el metro țawīl es empleado mayoritariamente en los panegíricos que aparecen en los A'māl, pero también se emplea para la sátira, el poema sapiencial o el amoroso. Igualmente, el metro kāmil y el basịt también se emplean para los elogios, el poema gnómico, la sátira o la nostalgia. Y otro tanto sucede con el resto de metros como el jafíf, wāfir, sarī', etc. Se puede decir que la preferencia que pueden tener los poetas por determinados metros se hace en función de la naturaleza del discurso a realizar (elogio, elegía, amor, etc.), y también de la mejor o peor capacidad de los metros para responder a ese propósito, pero aun así, como se ha dicho, sigue siendo ésta una cuestión todavía difícil de resolver.

En la elección de un metro u otro influyen también otros conceptos, como el de la musicalidad y la armonía que debe existir entre los componentes rítmicos de un metro y las palabras que dan forma a ese ritmo. Esto hace que ciertos metros ofrezcan mejores posibilidades a ciertos temas. Esta posibilidad vendría dada por el espacio de palabra que cada metro ofrece para la expresión de dicho tema. De esta manera metros como țawīl, kāmil, basịt y wāfir, son más largos y dan más espacio que otros más cortos, por lo que el criterio de la duración parece que también es importante, ya que responde a la intencionalidad que tiene el autor, al tema que desea expresar y a la estrategia lingüística que quiere dar a su poema. En su investigación, Khalid Chakor Alami también refiere que otro criterio que está presente en la elección de los metros es la celebridad que habían alcanzado determinados poemas que los poetas y literatos se sabían de memoria, lo cual hacía que los metros en los que estaban compuestos adquiriesen mayor valor. Esto es así, de tal manera que cuando un poeta quería componer una poesía recurría a su memoria y empleaba los modelos poéticos memorizados donde había ya una asociación fuerte establecida entre unos temas y unos metros. Es posible que los poetas pensaran que utilizando los supuestos metros célebres para sus poesías conseguirían la misma celebridad que habían logrado los anteriores poemas. No obstante, la respuesta a todas estas cuestiones e interrogantes está a la espera de futuros trabajos que puedan arrojar un poco más de luz.

Lo que sí parece claro es que los estudios actuales no hacen sino confirmarnos la falta de una verdadera evolución de la métrica árabe dentro de la poesía árabe clásica y cómo los poetas han ido imitando o siguiendo a lo largo de los siglos las pautas trazadas por lo poetas orientales de los primeros siglos del islam. Los límites de la originalidad de la poesía árabe, tanto en metro como en forma, son bastante estrechos, y ello ha sido sin duda debido a que la poesía árabe alcanzó muy pronto un gran desarrollo que cerró rápidamente las puertas a cualquier cambio o innovación. 